\section{Production Method and Cultivar Effects on Garlic Over-wintering Survival, Bulb Quality, and Yield}

\author{
S. Alan Walters ${ }^{1,2}$
}

AdDitional INDEX wORDs. Allium sativum, plasticulture, specialty vegetable

SUMMARY. Garlic (Allium sativum) is a popular specialty vegetable sold at many local market venues. Recently, the demand for high-quality garlic has prompted grower interest in producing this crop for direct markets. A 2 -year study was conducted at the Southern Illinois University Horticulture Research Center in Carbondale to evaluate eight currently recommended garlic cultivars on a silty loam soil, as well as compare garlic produced on bare soil during the winter and wheat (Triticum aestivum) straw mulch in the spring to black plastic. 'Idaho Silverskin' (softneck, silverskin type) and 'Persian Star' (hardneck, purple-stripe type) were the best cultivars of those evaluated for the lower midwestern United States based upon various yield and quality characteristics. 'Idaho Silverskin' and 'Persian Star' had $100 \%$ winter survival (regardless of production method), high bulb quality, low amounts of foliar disease, high marketable yields with low cull production ( $>96 \%$ of bulblets developed marketable bulbs), and low amounts of bulb rot $(<7 \%)$. Black plastic provided greater winter protection for garlic ( $95 \%$ survival rate) compared with bare soil ( $85 \%$ survival rate). Greater marketable weights and bulb diameters $\mathbf{5 0 \%}$ and $\mathbf{2 3 \%}$ increase, respectively) resulted when garlic was grown in black plastic compared with the bare soil/wheat straw mulch treatment.

A lthough $\approx 85 \%$ of U.S. garlic is produced in California and an additional 5\% to 6\% in Oregon and Nevada (U.S. Department of Agriculture, 2007; Western Integrated Pest Management Center and Alliance for Alternative Agriculture, 2004), it is a popular local specialty vegetable item at farmer's markets and other similar markets in the midwestern United States (Rosen et al., 2006; Walters et al., 2007). The recent demand for high-quality garlic has prompted grower interest in producing this crop for direct markets in the midwestern United States. The popularity of garlic has increased in recent years, probably resulting from consumer familiarity, as it is widely used as an ingredient in many culinary dishes and provides many health benefits (Cimmarrusti and Shoemaker, 2004; Rosen et al., 2006; Walters, 2007). Furthermore, consumers tend to purchase those products in which they have some familiarity with their preparation (Walters et al., 2007) as well as perceive some nutritional or health benefits (Cox et al., 1998).

Most commercially available garlic cultivars are classified as hardneck

${ }^{1}$ Department of Plant, Soil, and Agricultural Systems, Southern Illinois University, Carbondale, IL 629014415

${ }^{2}$ Corresponding author. E-mail: awalters@siu.edu.
(Allium satioum ssp. ophioscorodon) or softneck (A. sativum ssp. sativum) types (Volk et al., 2004). Hardneck cultivars are cold hardy, produce scapes (or flower stalks), and have only a single layer of cloves around the stalk within the bulb, whereas softneck cultivars do not typically produce a scape and have 12 to 25 cloves arranged in three to six layers within the bulb (Volk et al., 2004; Walters, 2007). There are distinct types within each garlic subspecies, with rocambole, porcelain, and purple-stripe types of hardnecks, and silverskin and artichoke being softneck types. Hardneck types have generally been grown in the midwestern United States, as they tend to have greater winter survival and higher yields compared with softneck types (Bachmann, 2001; Rosen, et al., 2006). However, softneck types are also popular with growers, as these are often used to create garlic braids to sell at local markets for a value-added product.

The production of garlic in Illinois has been increasing during the last few years (Voigt, 2005). This is probably because of garlic being one of the easiest vegetables to grow in the midwestern United States because of the lack of significant disease and insect pest problems (Walters, 2007). Garlic is highly adaptable to sustainable or organic production systems, as adequate crops can be produced with few to no pesticides. Garlic has great potential for direct market sales as growers can obtain a reasonable return on small investments because few off-farm inputs are required to produce the crop. The objectives of this study were to determine the effects of cultivar and production method (bare soil/wheat straw mulch compared with black plastic) on garlic overwintering, bulb quality, and yield in southern Illinois.

\section{Materials and methods}

This study was conducted during 2005 and 2006 at the Southern Illinois University Horticulture Research Center in Carbondale. The experiment was designed as a splitplot with three replications. The two main plots consisted of garlic produced on bare soil/wheat straw mulch or 1.25 mil black plastic. About 2 inches of wheat straw mulch was applied to the bare soil treatment in early spring to provide weed control. For black plastic, garlic was planted once small holes were made in the plastic. Trickle irrigation was used for both production methods. Subplots consisted of eight garlic cultivars: Carpathian, Idaho Silverskin, Inchelium Red, Georgian Crystal, Metechi, Music Pink, Persian Star, and Spanish Roja. Although there are numerous garlic cultivars that could have been evaluated, these were chosen because they were recommended for the midwestern United States (Egel et al., 2004).

\begin{tabular}{llll}
\hline $\begin{array}{l}\text { Units } \\
\text { To convert U.S. to SI, } \\
\text { multiply by }\end{array}$ & U.S. unit & SI unit & $\begin{array}{l}\text { To convert SI to U.S., } \\
\text { multiply by }\end{array}$ \\
\hline 0.3048 & $\mathrm{ft}$ & $\mathrm{m}$ & 3.2808 \\
2.54 & inch(es) & $\mathrm{cm}$ & 0.3937 \\
0.4536 & $\mathrm{lb}$ & $\mathrm{kg}$ & 2.2046 \\
1.1209 & $\mathrm{lb} / \mathrm{acre}$ & $\mathrm{kg} \cdot \mathrm{ha}^{-1}$ & 0.8922 \\
0.0254 & mil & $\mathrm{mm}$ & 39.3701
\end{tabular}


Specific information for these cultivars is provided in Table 1 . All planting stock was obtained from Filaree Farm, Okanogan, Washington, with new planting material obtained each year.

Large uniform cloves were used as planting stock for all cultivars to prevent clove size from having an effect on the outcome of the study. Plots were $4 \mathrm{ft}$ long with garlic cloves planted 6 inches apart using double rows on raised beds that were $\approx 6$ inches high (16 plants per plot). Center-to-center row spacing was $6 \mathrm{ft}$. The field soil was a Hosmer silt loam (fine-silty, mixed, mesic Typic Fragiudalfs; Herman, 1979) with a $4.5 \%$ organic matter content and a $\mathrm{pH}$ of 6.5 .

Garlic was planted on 17 and 12 Oct. in 2004 and 2005, respectively. For both years, garlic plants grew for about 1.5 months after planting before going into the overwintering phase because of significant freeze events, and spring regrowth normally began in mid-March. Standard cultural practices for garlic in Illinois were used (Egel et al., 2004). Before bed formation, $40 \mathrm{lb} /$ acre nitrogen $(\mathrm{N}), 48 \mathrm{lb} /$ acre phosphorus $(\mathrm{P})$, and $88 \mathrm{lb} /$ acre potassium $(\mathrm{K})$ were broadcast. Beginning in mid-April and ending early-June, $45 \mathrm{lb} /$ acre $\mathrm{N}$ from calcium nitrate was applied through the drip fertigation system. Scapes were removed within 2 weeks of first appearing on garlic plants.

Garlic overwintering survival was determined 1 Apr., and plant vigor ratings were collected on 1 Apr., I May, and 1 June in 2005 and 2006. Plant vigor was rated as 1 to $3=$ poor (weak plant with little foliar growth), 4 to $6=$ average (acceptable foliar growth), and 7 to $9=$ high (excessive amounts of foliar growth). Garlic foliar diseases (Schwartz and Mohan, 1995 ) were rated mid-June each year from $0=$ no injury (necrosis) to $10=$ plant death. Garlic bulbs were harvested on 2 July and 30 June in 2005 and 2006, respectively. The number and weight of marketable and cull bulbs were determined. Furthermore, bulb diameters (in inches) were determined, as well as the percentage of bulbs in each plot having rot. Garlic bulbs were finally rated for quality [based on shape, compactness (no bulblets protruding from the bulb), and lack of rot or other defects] ranging from 1 to $3=$ poor, 4 to $6=$ average, and 7 to $9=$ excellent.

Data were subjected to analysis of variance procedures using the general linear models procedure of SAS (version 8.0; SAS Institute, Cary, NC) appropriate for a split-plot experimental design to determine the effects of production method and cultivar on the variables evaluated. Fisher's least significance difference test at $P \leq 0.05$ was used to make comparisons among treatments.

\section{Results}

The data were combined over the 2 years and were analyzed. The analysis indicated no interactions $(P>$
$0.05)$ between years and production method or cultivar for all dependent variables evaluated. Furthermore, no interactions $(P>0.05)$ were detected between production method and cultivar for bulb quality and foliar disease ratings, garlic yields, bulb diameter, and percentage bulb rot. However, interactions $(P \leq 0.05)$ between these two independent variables were observed for garlic overwintering survival and plant vigor ratings.

The overwintering survival of garlic depended on the cultivar and production method (Table 2). Bare soil resulted in less winter survival for most cultivars, although 'Idaho Silverskin' and 'Persian Star' had 100\%

Table 1. Garlic cultivars evaluated at Carbondale, Illinois, during 2005 and 2006.

\begin{tabular}{lll}
\hline Cultivar $^{\mathbf{z}}$ & \multicolumn{1}{c}{ Scientific name } & \multicolumn{1}{c}{ Type } \\
\hline Carpathian & A. sativum ssp. ophioscorodon & hardneck, rocambole \\
Georgian Crystal & A. sativum ssp. ophioscorodon & hardneck, porcelain \\
Idaho Silverskin & A. sativum ssp. sativum & softneck, silverskin \\
Inchelium Red & A. sativum ssp. sativum & softneck, artichoke \\
Metechi & A. sativum ssp. ophioscorodon & hardneck, purple-stripe \\
Music Pink & A. sativum ssp. ophioscorodon & hardneck, porcelain \\
Persian Star & A. sativum ssp. ophioscorodon & hardneck, purple-stripe \\
Spanish Roja & A. sativum ssp. ophioscorodon & hardneck, rocambole \\
\hline
\end{tabular}

${ }^{2}$ All cultivars obtained from Filaree Farm, Okanogan, WA.

Table 2. Garlic overwintering survival and plant vigor ratings as influenced by production system and cultivar at Carbondale, Illinois.

\begin{tabular}{lclll}
\hline & & \multicolumn{3}{c}{ Plant vigor $^{\mathrm{y}}$} \\
\cline { 3 - 5 } Production system/cultivar & Survival (\%) & \multicolumn{1}{c}{ ES } & MS & LS \\
\hline Bare soil/wheat straw mulch & & & & \\
$\quad$ Carpathian $^{\mathrm{x}}$ & $70.8 \mathrm{~cd}^{\mathrm{v}}$ & $2.0 \mathrm{efg}$ & $2.7 \mathrm{~g}$ & $2.7 \mathrm{~h}$ \\
Georgian Crystal $^{\mathrm{x}}$ & $81.3 \mathrm{bcd}$ & $2.9 \mathrm{def}$ & $4.4 \mathrm{ef}$ & $4.4 \mathrm{~g}$ \\
Idaho Silverskin $^{\mathrm{w}}$ & $100.0 \mathrm{a}$ & $1.8 \mathrm{fg}$ & $2.9 \mathrm{~g}$ & $4.5 \mathrm{~g}$ \\
Inchelium Red $^{\mathrm{w}}$ & $73.3 \mathrm{~cd}$ & $3.0 \mathrm{de}$ & $3.8 \mathrm{fg}$ & $4.8 \mathrm{fg}$ \\
Metechi $^{\mathrm{x}}$ & $70.8 \mathrm{~cd}$ & $2.7 \mathrm{defg}$ & $3.7 \mathrm{fg}$ & $5.6 \mathrm{de}$ \\
Music Pink $^{\mathrm{x}}$ & $95.0 \mathrm{a}$ & $4.8 \mathrm{bc}$ & $5.9 \mathrm{~cd}$ & $6.2 \mathrm{cde}$ \\
Persian Star $^{\mathrm{x}}$ & $100.0 \mathrm{a}$ & $1.3 \mathrm{~g}$ & $3.5 \mathrm{fg}$ & $4.8 \mathrm{fg}$ \\
Spanish Roja $^{\mathrm{x}}$ & $85.5 \mathrm{bc}$ & $4.0 \mathrm{~cd}$ & $5.8 \mathrm{cde}$ & $5.8 \mathrm{def}$ \\
Black plastic & & & & \\
Carpathian $_{\text {Georgian Crystal }}$ & $89.6 \mathrm{ab}$ & $3.7 \mathrm{~cd}$ & $4.0 \mathrm{fg}$ & $4.1 \mathrm{~g}$ \\
Idaho Silverskin $_{\text {Inchelium Red }}$ & $100.0 \mathrm{a}$ & $5.5 \mathrm{ab}$ & $7.6 \mathrm{ab}$ & $7.7 \mathrm{ab}$ \\
Metechi & $100.0 \mathrm{a}$ & $3.3 \mathrm{de}$ & $4.6 \mathrm{de}$ & $5.5 \mathrm{de}$ \\
Music Pink & $100.0 \mathrm{a}$ & $6.8 \mathrm{a}$ & $7.8 \mathrm{a}$ & $8.3 \mathrm{a}$ \\
Persian Star & $85.4 \mathrm{bc}$ & $5.4 \mathrm{ab}$ & $6.2 \mathrm{bcd}$ & $6.5 \mathrm{bcde}$ \\
Spanish Roja & $100.0 \mathrm{a}$ & $6.9 \mathrm{a}$ & $8.0 \mathrm{a}$ & $8.3 \mathrm{a}$ \\
\hline
\end{tabular}

${ }^{\mathrm{z}}$ Survival = garlic overwintering survival rate.

yPlant vigor was rated as $1-3=$ poor, 4-6 = average, and 7-9 = high aboveground foliar growth; and rated as ES = early season (1 Apr.), MS = midseason (1 May), and LS = late-season (1 June) during 2005 and 2006.

${ }^{x}$ Hardneck type of garlic.

woftneck type of garlic.

${ }^{v}$ Means followed by the same letter within each column are not significantly different at $P \leq 0.05$. 
survival regardless of production method. Garlic cultivars with poor overwintering survival $(<86 \%)$ in bare soil included Carpathian, Georgian Crystal, Inchelium Red, Metechi, and Spanish Roja; furthermore, the cultivars Carpathian, Metechi, and Spanish Roja had the lowest survival rates on black plastic $(<90 \%)$.

Plant vigor ratings were consistently lower throughout the growing season on bare soil/wheat straw mulch compared with black plastic (Table 2). For black plastic, the most vigorous cultivars were Music Pink, Inchelium Red, Georgian Crystal, and Spanish Roja, whereas Music Pink and Spanish Roja had the highest vigor in the bare soil/wheat straw mulch treatment.

Cultivars having high foliar disease ratings $(\geq 5.1)$ included Music Pink, Georgian Crystal, and Spanish Roja, whereas, those with low ratings $(\leq 2.5)$ included Idaho Silverskin, Inchelium Red, Carpathian, and Persian Star (Table 3). Foliar disease development on garlic depended on the production system with disease ratings higher on black plastic compared with the bare soil/wheat straw mulch production system. The foliar disease most often observed was purple blotch (Alternaria porri).

Garlic cultivars differed $(P \leq$ $0.05)$ for bulb quality with Persian
Star, Idaho Silverskin, Carpathian, and Georgian Crystal having high ratings ranging from 6.8 to 7.8 , whereas Metechi and Inchelium Red bulbs were of low quality with ratings less than 2.9 (Table 3 ). The production system did not affect garlic bulb quality.

Marketable garlic numbers were greatest with 'Idaho Silverskin' and 'Persian Star', whereas those with the lowest included 'Metechi' and 'Inchelium Red'. For marketable weights, several cultivars produced $\geq 1.6 \mathrm{lb} /$ plot, including Georgian Crystal, Idaho Silverskin, Music Pink, and Persian Star. 'Metechi' was the only cultivar evaluated that produced $<1.0 \mathrm{lb} /$ plot. 'Metechi' and 'Inchelium Red' produced high numbers and weights of cull bulbs, whereas other cultivars such as Idaho Silverskin, Carpathian, and Persian Star produced little to none (Table 3 ). Although greater garlic marketable weights were produced on black plastic compared with bare soil/wheat straw mulch, the two production systems did not differ for numbers of marketable and cull bulbs or weights of cull bulbs.

Although most garlic cultivars were similar for bulb diameter ranging from 5.2 to 5.7 inches (Table 3 ), differences $(P \leq 0.05)$ were detected between the two cultivars with the lowest diameter (Carpathian and Metechi at 4.6 inches) and Inchelium Red, which had the largest diameter at 6.7 inches. The two production systems differed for bulb diameter, as garlic grown in black plastic had increased diameters by $\approx 24 \%$ compared with those grown in bare soil/ wheat straw mulch.

The percentage of bulb rot (primarily basal rot caused by (Fusarium culmorum) differed $(P \leq 0.05)$ among garlic cultivars (Table 3 ). Garlic cultivars with low amounts of bulb rot $(\leq 10.3 \%)$ included Idaho Silverskin, Persian Star, and Carpathian. All other cultivars had greater than 23\% bulb rot, with Spanish Roja, Inchelium Red, and Metechi having the highest levels at $\approx 39 \%, 40 \%$, and $46 \%$, respectively. No differences $(P>$ 0.05 ) were detected between the two production systems for bulb rot.

\section{Discussion}

Garlic is widely grown in the midwestern United States by growers that sell at local direct markets because of the respectable revenues generated from minimal investments and inputs. Cultivar selection and the production system used (e.g., bare soil, wheat straw mulch, black plastic, etc.) are two important criteria that should be considered before planting garlic. Although several

Table 3. Garlic foliar disease ratings, bulb yields, and bulb quality characters as influenced by cultivar and production system at Carbondale, Illinois.

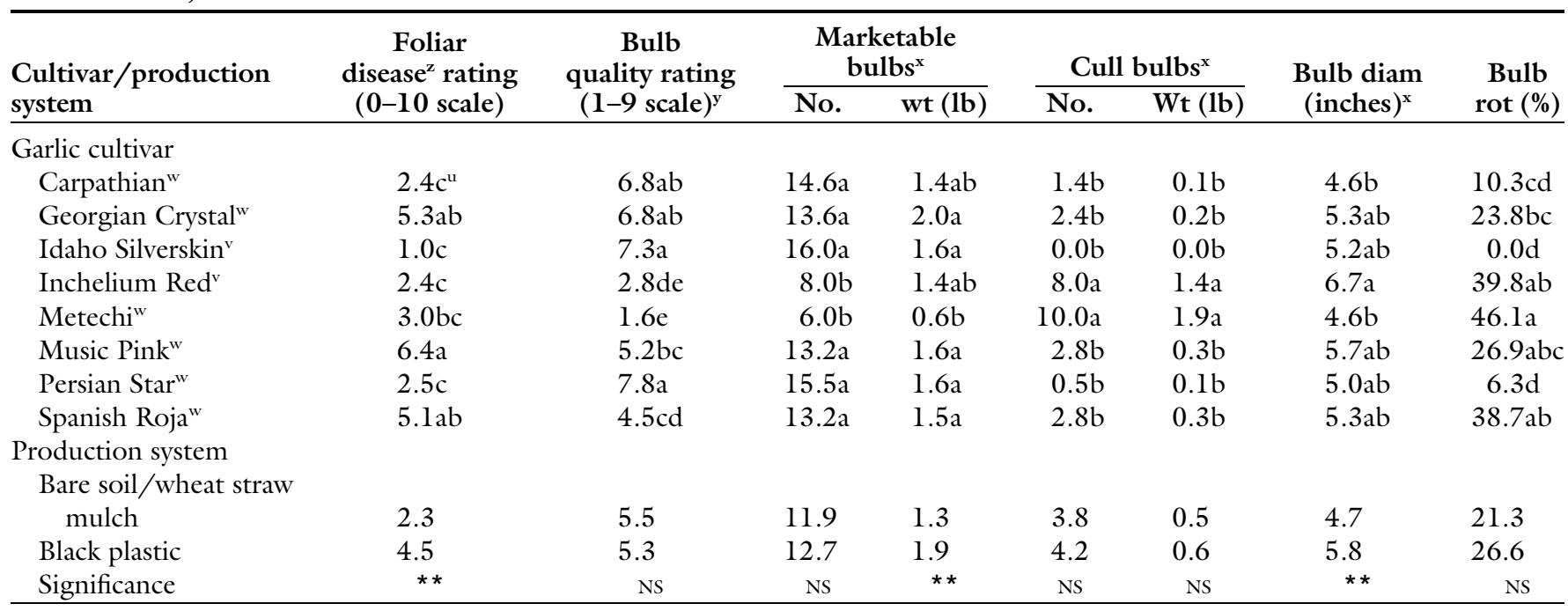

${ }^{\mathrm{z}}$ Garlic foliar diseases were rated mid-June each year from $0=$ no injury (necrosis) to 10 = plant death.

'Bulb quality was rated from $1-3=$ poor, $4-6$ = average, and 7-9 = excellent.

xields based on 16 plants grown at 6-inch in-row spacings on double rows in 4 - $\mathrm{ft}$-long plots; $1 \mathrm{lb}=0.4536 \mathrm{~kg}, 1 \mathrm{inch}=2.54 \mathrm{~cm}, 1 \mathrm{ft}=0.3048 \mathrm{~m}$.

"Hardneck type of garlic.

"Softneck type of garlic.

"Means followed by the same letter within each column are not significantly different at $P \leq 0.05$.

Ns, ${ }^{* *}$ Nonsignificant at $P \leq 0.05$ or significant at $P \leq 0.01$, respectively, for comparison of production systems. 
garlic cultivars are recommended for the midwestern United States (Egel et al., 2007), Idaho Silverskin (softneck, silverskin type) and Persian Star (hardneck, purple-stripe type) were the best cultivars of those evaluated for the lower midwestern United States based upon this study. 'Idaho Silverskin' and 'Persian Star' had high overwintering ability, high bulb quality, low foliar disease development, high marketable yields, low cull production, and low bulb rot (Tables 2 and 3). Although 'Carpathian' had low overwintering ability, it had other characteristics similar to 'Idaho Silverskin' and 'Persian Star'; thus, for a hardneck, rocambole type, 'Carpathian' may be a suitable choice to grow in the lower midwestern United States environment. 'Music Pink' would probably be the best choice for a hardneck, porcelain type because it had high overwintering ability, high vigor, high marketable yields, and low cull production; however, it had high foliar disease development, below average bulb quality, and high amounts of bulb rot (Tables 2 and 3). 'Music Pink', 'Carpathian', and 'Persian Star' were hardnecks that performed well in our study, as well as in northeastern Illinois (Voigt, 2005). However, three hardneck cultivars (Georgian Crystal, Metechi, and Spanish Roja) that were suggested by Voigt (2005) had several production problems and did not generate adequate yields in southern Illinois. Because of the limited number of garlic cultivars currently recommended for the midwestern United States (Egel et al., 2007), future research should focus on evaluating a broader array of cultivars to provide growers with a wider selection of adapted hardneck and softneck types.

Although most midwestern U.S. growers use bare soil for garlic production, it appears, based on our research, that black plastic will provide greater winter protection (Table 1). Guenther and Stonaker (2006) found higher garlic yields resulted when a floating row cover or organic mulch was used during the winter months compared with no protection. Furthermore, Bratsch et al. (2005) found that straw mulch increased garlic bulb weights and yields, percentage of marketable bulbs, as well as bulb diameter and bulblet numbers per bulb. Our study also detected higher garlic marketable weights and bulb diameters when grown in black plastic compared with bare soil that had no protection over the winter months (Table 3). Garlic emerged from the overwintering phase sooner and started to grow quicker in the spring on black plastic compared with the bare soil/wheat straw mulch treatment (Table 2), which most likely led to the greater plant vigor, yield, and bulb size observed for black plastic. However, foliar diseases were more severe on black plastic compared with the bare soil/wheat straw mulch treatment. This most likely resulted from the higher soil surface temperatures reached in late May and June on the black plastic that provided optimum conditions for disease development. Because most growers use bare soil for garlic production compared with black plastic, greater winter survival and yields on bare soil may result if more protection is provided to plants (e.g., use of some type of organic mulch) during the winter months. Thus, the effects of different mulches, including various organic and synthetic materials on garlic overwintering and subsequent yields, should be considered in future research.

\section{Literature cited}

Bachmann, J. 2001. Organic garlic production. Appropriate Technology Transfer for Rural Areas (ATTRA) Publ. CT146. 23 June 2007. <http://attra. ncat.org/attra-pub/PDF/garlic.pdf>.

Bratsch, T., R. Morse, Z.X. Shen, and B. Benson. 2005. No-till organic culture of garlic utilizing different cover crop residues and straw mulch for over-wintering protection, under two seasonal levels of organic nitrogen. Virginia Veg. Small Fruit Specialty Crop Nwsl. 4(6):25-30. July 2007. <http://www.ext.vt.edu/ news/periodicals/commhort/2005-11/ november2005.pdf>.

Cimmarrusti, D. and W.H. Shoemaker. 2004. 2003 Garlic cultivar evaluation, p. 88-89. In: D.H. Naylor, S.K. Naylor, and J. Masuinas (eds.). Trans. Illinois State Hort. Soc. Vol. 137 and 7th Ann. Illinois Fruit Veg. Res. Rpt., Urbana, IL.

Cox, D.N., A.S. Anderson, J. Reynolds, S. McKellar, M.E.J. Lean, and D.J. Mela. 1998. Take five, a nutritional education intervention to increase fruit and vegetable intakes: Impact on consumer choice and nutrient intakes. Br. J. Nutr. 80:123131 .

Egel, D., F. Lam, R. Foster, E. Maynard, R. Weinzierl, M. Badadoost, H. Taber, R. Bauernfeind, T. Carey, M. Kennelly, B. Hutchison, and L. Jett. 2007. Midwest vegetable production guide for commercial growers 2007. Univ. Illinois Ext. Bull. C1373-07.

Egel, D., F. Lam, E. Maynard, R. Weinzierl, M. Badadoost, H. Taber, B. Hutchison, and L. Jett. 2004. Midwest vegetable production guide for commercial growers 2004. Univ. Illinois Ext. Bull. C1373-04.

Guenther, D. and F. Stonaker. 2006. Organic garlic research in Colorado: Winter mulching, irrigation systems, spacing, scape removal, and flame cultivation. HortScience 4l(4):987. (Abstr.).

Herman, R.J. 1979. Soil survey of Jackson County, Ill. Illinois Agr. Expt. Sta. Soil Rpt. 106.

Rosen, C., R. Becker, V. Fritz, B. Hutchison, J. Percich, C. Tong, and J. Wright. 2006. Growing garlic in Minnesota. Univ. Minnesota Ext. Publ. WW-07317. 11 May 2007. <http://www.extension.umn.edu/ distribution/cropsystems/DC7317.html>.

Schwartz, H.F. and S.K. Mohan. 1995. Compendium of onion and garlic diseases. APS Press, St. Paul, MN.

U.S. Department of Agriculture. 2007. Statistics of vegetables and melons. 19 Sept. 2007. <http://www.nass.usda. gov/Publications/Ag_Statistics/2007/ CHAP04.pdf>.

Voigt, C. 2005. 2005 Garlic trial in northeastern Illinois, p. 143-148. In: D.H. Naylor and J. Masuinas (eds.). Trans. Illinois State Hort. Soc. Vol. 139 and 9th Ann. Illinois Fruit Veg. Res. Rpt., Urbana, IL.

Volk, G.M., A.D. Henk, and C.M. Richards. 2004. Genetic diversity among U.S. garlic clones as detected using AFLP methods. J. Amer. Soc. Hort. Sci. 129:559-569.

Walters, S.A. 2007. Garlic. Horticulture Factsheet \#3, College Agr. Sci., Southern Illinois Univ., Carbondale.

Walters, S.A., B.H. Taylor, and W. Moon. 2007. Appeal of specialty vegetables to consumers. HortScience 42(4):892. (Abstr.).

Western Integrated Pest Management Center and Alliance for Alternative Agriculture. 2004. Crop profile for garlic in California. 17 Sept. 2007. <http://www. ipmcenters.org/cropprofiles/docs/ CAgarlic.html>. 